\title{
Migration and development at home: Bitter or sweet return? Evidence from Poland
}

Jan Brzozowski and Nicola Daniele Coniglio

SERIES Working PAPERS N. 08/2016

SERIES sono pubblicati a cura del Dipartimento di Scienze economiche e metodi matematici dell'Università degli Studi di Bari "Aldo Moro". I lavori riflettono esclusivamente le opinioni degli autori e non impegnano la responsabilità del Dipartimento. SERIES vogliono promuovere la circolazione di studi ancora preliminari e incompleti, per suscitare commenti critici e suggerimenti. Si richiede di tener conto della natura provvisoria dei lavori per eventuali citazioni o per ogni altro uso.
SERIES are published under the auspices of the Department of Economics of the University of Bari. Any opinions expressed here are those of the authors and not those of the Department. Often SERIES divulge preliminary or incomplete work, circulated to favor discussion and comment. Citation and use of these paper should consider their provisional character. 


\title{
Migration and development at home: Bitter or sweet return? Evidence from Poland
}

Jan Brzozowski (Cracow University of Economics, Poland) and Nicola Daniele Coniglio (University of Bari „Aldo Moro”, Italy)

[the final, definitive version of this paper has been published in "European Urban and Regional Studies" by SAGE Publications Ltd, All rights reserved (C) The authors Nicola D. Coniglio and Jan Brzozowski]

\begin{abstract}
The existing economic literature focuses on the benefits that return migrants offer to their home country in terms of entrepreneurship, human and financial capital accumulation. However, return migration can have modest or even some detrimental effects if the migration experience was unsuccessful and/or if the migrant fails to reintegrate into the home country's economy. In our paper, we empirically show which factors - both individual characteristics and features related to the migration experience - influence the likelihood of a sub-optimal employment of returnees' human capital employing an original dataset on a representative sample of return migrants in Silesia (Poland).
\end{abstract}

Keywords: return migration, international migration, economic performance, regional development

JEL code: O15 Human Development and Migration, F22 International Migration, J24 Human Capital and Occupational Choice, R23 Regional Labor Markets

Contact details: Nicola D. Coniglio, University of Bari "Aldo Moro", Dept. of Economics and Mathematics, Largo Abbazia Santa Scolastica, 70124 Bari (Italy), email: Nicoladaniele.coniglio@uniba.it; Jan Brzozowski, Cracow University of Economics, Dept. of European Studies, Rakowicka 27, 31-510, Cracow (Poland), email: jan.brzozowski@uek.krakow.pl 


\section{Introduction}

Return migration is one of the most important channels through which sending countries might benefit from emigration. In fact, the returnees can be an important source of financial (remittances sent and savings brought upon return), social (transnational networks developed and maintained with the former destination countries, transfer of social norms, democratic values) and human capital (additional education, skills and professional experience acquired during the migration period; see Thomas-Hope 1999). Yet, return migration does not automatically translate into the development of the source country or region, as there are complex migrant-home development interactions (De Haas, 2010). Moreover, the returnees do not constitute a homogenous group but return migration - as for initial emigration - is characterized by self-selection ${ }^{1}$. Looking at employment patterns of the returnees might be misleading when it comes to assessing their pro-development potential. Many returnees start businesses in their home country using the human and financial capital gained overseas (Mayer et al., 2015). However, McCormick and Wahba (2001) suggest that some unskilled return migrants become self-employed because of the lack of other alternative employment possibilities at home, and therefore their job-creating and development potential for the source countries can be rather small (Piracha and Vadean, 2010). The analyses of special programs encouraging the return of diaspora members show that such policies can encourage more productive uses of remittances, but often fail to exploit the skills of the returnees, which is often caused by the shallowness of the labour markets in the home economy (Diatta and Mbow, 1999).

The recent global financial crisis has boosted the academic and policy interest in the nexus between return migration and development. The deterioration of economic opportunities in several migrant destination countries after 2007 not only has contributed to a decrease in migration intensity, but has spurred a large return migration (Tilly, 2011). These new developments are particularly intensive in the case of the Central and Eastern European (henceforth CEE) countries which benefit from the principle of free mobility of people within the EU. Martin and Radu (2012) suggested that in the case of the recent East-West European migration, it was reasonable to expect a return ratio in the range of 20-50 per cent of the initial flows. For instance, the data from Polish Labour Force Survey (BAEL) shows that between January 2004 and June 2008, 580 thousand persons returned from international migration, with 213 thousand alone in 2007 (Anacka and Fihel 2012). The Polish case is notable, as Poland was one of the few EU Member States which remained relatively unharmed by the

\footnotetext{
${ }^{1}$ For the US, Borjas and Bratsberg (1996) find that return migration reinforces the same skill-selectivity of the initial migration flows. Whether return migrants are positively or negatively self-selected is highly context- and country-specific. For instance, Coniglio et al. (2009) find evidence of a positive self-selection of returnees when considering irregular immigrants residing in Italy.
} 
economic crisis, retaining a positive economic growth in the period 2007-2009. So while a vast number of Poles remained abroad in countries harmed by the crisis - frequently taking advantage of social benefits or simply being able to retain their jobs (Krings et al. 2009) many others returned to Poland, lured by the relatively favourable economic situation at home and by the active government policy towards Polish diaspora, which encouraged the return of post-accession migrants (Brzozowski 2011).

In spite of the intensive return waves of migrants - in particular from Central and Eastern Europe - there exists limited evidence on the economic implications of such labour movement back to source countries (see de Coulon and Piracha 2005, Iara 2006 and Martin and Radu 2012). Moreover, the knowledge on whether and under which circumstances the returnees are able to productively exploit the skills acquired during the migration spell is generally scarce in the migration studies literature.

The main aim of this paper is to analyze the factors which prevent successful return migration to the home country (we label the occurrence of this event as a 'bitter return'). In particular we explore how the experiences acquired during the migration spell influence the probability of succeeding once the migrant returns to the home region.

We firstly discuss the evidence on return migration and on the migrants' performance upon return. Secondly, we carry out an empirical analysis of the determinants of unsuccessful return migration using an original and rich dataset on the migrants returning from several European countries to the Silesia region in Southern Poland. We explore three different dimensions: i) the probability of employing the skills and qualification acquired during the migration spell; ii) economic inactivity upon return; iii) the probability of experiencing difficulties and hardships upon return (i.e. a 'bitter return'). Given the current migration history of Poland, the most important source country within the EU, we believe that this case study has significant general implications.

We find that younger and more qualified migrants are less likely to experience an unsuccessful return, in particular if the initial outmigration was motivated by educational and training purposes. A longer migration spell reduces the likelihood of a skill waste upon return but, in general, is associated with more intense difficulties and hardships in re-entering the home country society and labour market. We find strong evidence of a 'repeated skill waste': individuals experiencing a skill mismatch during the migration experience, ceteris paribus and controlling for the endogeneity of this outcome, are more likely to be economically inactive and less likely to use the newly acquired human capital once back in the home country. Finally we find evidence that those individuals who managed to accumulate savings during the migration spell are more likely to be economically inactive and experience a skill waste upon return. The capital and skills accumulated abroad during the migration spell are not necessarily used in a complementary way in the home country.

The structure of our paper is as follows. In the second section we briefly review the literature on return migration and, in particular, on the economic contribution of returnees upon return. 
In Section 3 we firstly describe the data-set and the empirical methodology used and we present the empirical analysis. Section 4 reports concluding remarks.

\section{Bitter return? A conceptual discussion}

When is return migration an optimal strategy from the point of view of the migrant? Do migrants contribute to their home country's economy when they return? The economic research on return migration can be broadly divided into two main strands surrounding these two questions. The first strand of literature has focused on the economic determinants of return migration, and in particular on the role of push and pull factors, respectively in the host and home locations, which might influence the homecoming decision. In the standard neoclassical theory, return migration is generally seen as the result of the failure of the migration project due to the fact that the migrant has not succeeded in integrating economically and/or socially in the host country (De Haas et al. 2014) or, in the case of irregular migration, if the migration spell is forcefully interrupted by the host country's authorities. In the latter case, the migration spell is sub-optimal if compared with the premigration expectations.

Using the 'lenses' of the new economics of labour migration, the unit of analysis is not the single individual but the household. The migration project is a collective venture of the migrant's household, which should lead - via remittances and capital accumulated abroad - to the betterment of the living conditions of the migrant's entire family residing in the home country, including the migrant. Therefore, in this framework the successful migration project is usually temporary, as the migrant intends to return in order to employ the resources accumulated during the migration spell in a productive activity for the benefit of his/her household (Dustmann 1997, Stark et al., 1997). In this framework, the return decision might be postponed when the migrant is not successful in achieving the goal set for the migration project (De Haas et al. 2014). Several studies that have tested those contrasting theses find mixed and heterogeneous results (Jensen and 2007, Fokkema and De Haas 2015, De Haas et al. 2014, Bijwaard et al. 2014, Bijwaard and Wahba 2014). As argued by De Haas et al. (2014), there exist several theoretical explanations for return migration and the approaches highlighted above should be treated as complementary, not rival concepts to describe the overall process that leads to the patterns observed in migration flows (De Haas et al. 2014).

The second strand of the existing literature deals with the returnees' economic performance in the home country. These studies generally focus on the occupational choice of migrants returning to the home country (wage employment, self-employment and entrepreneurial activities, but also unemployment and non-participation in the labour market) and/or their personal characteristics (whether they are positively or negatively self-selected compared to migrants and non-migrants). The theoretical explanation for these studies is provided mostly by the structural approach in migration studies. The structuralists consider how the returnees' 
expectations are influenced by the socio-institutional factors in their home countries (De Haas et al. 2014).

The seminal work of Cerase (1974) defines a useful categorization of return migration: "return of failure", "return of conservatism", "return of retirement" and "return of innovation". Only the last type, the return of innovation opens a possibility for migrants to become agents of change and helpers of modernization process in their source country. Still, the author is rather pessimistic about the effective "innovative" impact of the returnees, as those become constrained by the local power structures which are resilient to socio-economic changes (Cerase 1974). Moreover, as Gmelch (1980) adds, the returnees tend not to be well-prepared for return, usually making a very naive and optimistic assumption about the socio-economic situation at home, which in turn explains their poor performance upon homecoming. This pessimistic hypotheses have been tested in a number of studies. Diatta and Mbow (1999: 254) focus on the Senegalese diaspora, claiming that the skills learned by migrants "have been put to little use" upon return, constraining them to salaried employment. De Vreyer et al. (2010) find that return migrants from OECD countries get a substantial wage premium upon return to West African countries, but the returnees - probably due to lost social capital as compared to non-migrants - show smaller participation rates in the formal wage sector. These findings suggest that the characteristics of both origin and destination countries matter in explaining (un)successful return migration.

De Coulon and Piracha (2005) find that the returnees in Albania are negatively self-selected and typically underperform the non-migrant population in the home-country labour market. However, they also observe a premium stemming from the migration experience on the labour market, suggesting that returnees have acquired some skills that make them more productive in the home-country labour market. Iara (2006) finds that the young male returnees from Western Europe receive a substantial wage premium on the labour markets in Central and Eastern Europe. However, her analysis shows the existence of a positive self-selection of both out-migrants and returnees. A positive self-selection in return migration is also found in the study of Martin and Radu (2012) for Poland, Hungary, Czech Republic and Slovakia. These authors find evidence of an earning premium associated to the migration experience. However, their study points to the fact that returnees - due to weak social networks and/or to lack of experience related to the local labour market - often choose self-employment or remain economically inactive upon return.

Most of the studies on the performance of return migrants do not fully investigate how the characteristics of the migration experience of the returnees account for the successful economic re-integration in the home country. In this regard, two notable exceptions need a closer attention. Williams and Balaz (2005) study the process of human capital acquisition during the migration spell of three distinct groups of returnees in Slovakia: professionals and managers, students and au pairs. The authors argue that less than half of their respondents make use of the skills and competences acquired abroad. 
In a related study, Lianos and Pseiridis (2009) investigate the performance of return migrants in Bosnia, Bulgaria, Georgia, Kyrgyz Republic, Romania, and Tajikistan, taking into account the acquisition of qualifications and skills during the migration spell. In their study, the migrants who worked in the host country in the same sector as before migration were more likely to get valuable on-the-job skills; on the contrary a job-mismatch was generally less conducive to human capital acquisition. Interestingly, the authors find that migrants whose economic situation before migration was unfavourable were also more likely to acquire onthe-job skills compared to migrants with university education. Moreover, the skills learned during the migration spell result in a substantial (on average by 16 per cent) increase in the earnings upon return. These two studies highlight the important (and heterogeneous) role played by human capital acquisition during the migrants' stay abroad on their performance upon return.

The two strands of literature briefly outlined above are generally detached from each other. Most studies on the economic performance and contribution of return migrants do not explicitly take into account the characteristics of the migration spell. The working experience of the migrant in host country, the learned skills and acquired human capital, but also one's failures, traumas and mistakes are seldom included to account for the variation of the economic performance at home upon return. We argue in the present work that a full understanding of the re-integration processes of the returnees in the home country should duly take into consideration the entire migration experience of the individuals (and not only their characteristics).

\section{Bitter return: empirical analysis}

\section{Data description}

The data-set for our study is based on a household-level survey conducted in Silesia, an administrative region in southern Poland. This is a region with a rich history of migration, especially to the US and Germany. However, Silesia is also a traditional industrial region, where the coal mines, chemical and automobile industry still remain an important part of the regional economy. Additionally, the region as compared to national Polish economy, is relatively well-developed, with the average monthly earnings over the national average (103,7\% in 2013; see CSO 2015). This is an added value of our approach, as most of the studies on return migration focused on the developing and emerging/transforming economies. Consequently, the choice of this region for our analysis is interesting, as we investigate the effects of return migration to a high-income and fast-growing economy, which has a relatively high potential to exploit the skills and competences of the returnees.

The household survey was carried out in April 2011 and covered 17,600 randomly sampled households, which accounts for ca. $1 \%$ of the total population in the Silesia region. Out of 
those, 1,214 households experienced migration of at least one household member and have been the object of further investigation ${ }^{2}$. Using CATI (Computer-Assisted Telephone Interviewing) technique, interviews with respondents were carried out, resulting in 528 complete questionnaires for return migrants and 686 for international migrants (or more precisely with the members of the families of the migrants). One possible shortcoming related to the data collection method is the fact that our sample underestimates the magnitude of international migrants as the households entirely composed of migrants are not included. However, for the purpose of the present study this is not a major problem, as our focus is on the returnees only. Consequently, we can argue that our sample is fully representative for the returnees' population in the region.

In Table 1 we report the main characteristics of return migrants to the Polish region under analysis. We distinguish between the migrants who face significant difficulties and hardships upon return in Poland (labelled as bitter return ${ }^{3}$, column 2) and those who do not experience such difficulties (labelled as sweet return, column 3).

\section{TABLE 1 -HERE}

The returnees in our sample are - on average - rather young, mostly male and with a rather large share of those who have completed vocational education. The most popular country of destination was the UK, followed by Germany. The statistics are basically reflecting the general trend in post-accession migration from Poland after 2004 and subsequent return waves (Fihel and Anacka 2012). There exist some substantial differences between migrants experiencing sweet and bitter return as reported in the last column of the table. Those more successful upon return tend to be slightly older, more likely to have children and tertiary rather than vocational education. Individuals who have returned in more recent years - most likely 'pushed' by the financial crisis - are slightly more likely to experience difficulties upon return. Finally, the country where individuals have migrated seems to matter: bitter returnees are less likely to be among those who returned from Germany and more likely to be among those returning from The Netherlands, Ireland and Italy. Clearly the country of migration might matter both in terms of the initial self-selection process into alternative destinations and in terms of the heterogeneous possibility to accumulate experiences and human capital during the migration spell. For instance, for Silesia, Germany represents a more traditional country of destination with presumably a more dense diaspora and, in turn reduced

\footnotetext{
${ }^{2}$ The definition of migrant adopted for the purpose of the survey is the individual who migrated to a foreign country between 2004 and 2011 for a period of minimum 3 months.

${ }^{3}$ The definition of bitter return is based on self-declared difficulties faced by the returnees such as the lack of/poor access to reliable information on formalities required upon return and no or weak support in the process of finding opportunities in the labour market.
} 
costs of economic and social integration. On the contrary, migration in Italy is often characterized by a rather low socio-economic integration and often the migration spell is conducted irregularly ${ }^{4}$.

\section{Empirical methodology: probit and seemingly unrelated bivariate probit models}

What determines an unsuccessful return both from the point of view of the returnee and of the home country society? In what follows we analyse the individual and household level factors which are associated with the probability of experiencing a sub-optimal use of the skills and human capital accumulated during the migration spell.

In particular we explore four dimensions of unsuccessful return employing the following alternative dependent variables: i) skill waste upon return, a dummy variable equal to 1 if the returnee is not currently able to use the experiences and skills learned abroad; ii) economic inactivity, a dummy variable equal to 1 if the returnee is not currently economically active/employed; iii) bitter return, a dummy variable equal to 1 if the returnee experiences significant hardships/difficulties upon return in the home country socio-economic context; iv) job-related difficulties, a dummy variable equal to 1 if the returnee experience significant difficulties in the home country labour market.

Our estimation strategy is based on the following baseline equation:

$$
\operatorname{Prob}(\text { Unsuccessful_Return })=\alpha+\beta * X_{i}+\gamma * \text { Skill_Waste_HostCountry } y_{i}+\varepsilon_{i}
$$

where the probability of an unsuccessful return (using the above-mentioned dependent variables) depends on a vector $X_{i}$ of individual (age, sex, type of educational background, employment status before migration), household (children, economic situation before migration, relative importance of remittances for household consumption) and migration experience characteristics (study-related migration, migration spell, year of return in Poland, irregular migration, use of social assistance during the migration spell, country of migration, skills acquired during migration). We report the descriptions and summary statistics of all the dependent variables and covariates used in this study in Appendix 1 .

Our model includes the variable Skill Mismatch in the host country, a dummy variable equal to 1 when the return migrant was overqualified for the type of occupation in which he/she was

\footnotetext{
${ }^{4}$ In our sample, more than one third of the returnees who had an irregular status during their migration spell were residing in Italy.
} 
employed abroad. Our main hypothesis is that the sub-optimal employment of skills and human capital during the migration spell might translate into a persistent sub-optimal use of human capital also at the end of it. In fact, if a migrant is not fully using his/her skills and qualifications in his/her employment abroad he/she might be induced to acquire little additional human capital and, most likely, of the type that is not necessarily of high potential upon return to the home country. Clearly a skill mismatch during migration might be endogenous with respect to our dependent variable since some characteristics of the migrant might explain the skill waste experienced both during and after migration. As discussed by Baum et al. (2012), the estimation of binary models with endogenous binary regressor is not straightforward. Following Baum et al. (2012) we estimate a bivariate probit model as follows:

$$
\begin{aligned}
& \operatorname{Prob}(\text { Unsuccessful_Return })=\alpha+\beta^{*} X_{i}+\gamma^{*} \text { Skill_Waste_HostCountry }_{i}+\varepsilon 1_{i} \\
& \operatorname{Prob}\left(\text { Skill_Waste_HostCountry }{ }_{i}\right)=\alpha+\theta^{*} Z_{i}+\varepsilon 2_{i} \\
& (\varepsilon 1, \varepsilon 2, X, Z) \sim N(0,0,1,1, \rho)
\end{aligned}
$$

where the two probit models (2), (3) are simultaneously estimated through maximum likelihood estimation and the model permits to estimate the parameter $\gamma$, i.e. the effect of the skill waste during migration on the subsequent unsuccessful return, allowing for the correlation of the errors terms $(\rho)$.

In Table 2 we report the marginal effects of both probit and bivariate probit models when our dependent variable is the skill waste upon return. The probability of experiencing a skill waste upon return is between 10,7 and $12,6 \%$ higher when the migrant was overqualified during the migration spell when we do not control for potential endogeneity (columns 1-3, probit models). The likelihood of skill waste goes up to $38,1 \%$ when accounting for endogeneity (column 1a) $)^{5}$. Younger returnees are less likely to experience a skill waste upon return; moving from mean age (approximately 35 years old) to one standard deviation above it (circa 47 years old) increases the probability of not using the acquired skills and experiences by 6$7 \%$. We also find mild evidence of a higher probability of skill waste upon return for female migrants.

Individuals with tertiary education are between $13-15 \%$ less likely to experience a skill waste once they return home. A similar effect is found for those who were working before migrating

\footnotetext{
${ }^{5}$ Note that we find only weak evidence of endogeneity of the skill mismatch in the host country on skill waste upon return. Table 2 reports the LR test on $\rho=0$ which is significant at $10 \%$ level only when considering the most parsimonious model reported in column 1 .
} 
and for migration related to study and training reasons. The latter result suggests the importance of cross-boundary migration for study and training reasons for the home country socio-economic development. This type of return migration is well identified by the abovementioned Cerase's category of 'return of innovation' (Cerase, 1974).

A longer migration spell is, ceteris paribus, associated with a lower probability of not using the skills accumulated while abroad: an increase of the migration duration of one standard deviation above the mean decreases the probability of skill waste upon return of circa $7 \%$. We control for the year of return and find a negative but not significant effect on the occurrence of the skill waste.

TABLE 2 -HERE

Our results show that the type of migration experience significantly affects the ability to use skills and competence acquired abroad. In Column 2 we introduce a dummy which is equal to 1 when the status of the migrant was not regular and find some support for an increase in the probability of skill waste. In fact, irregular migrants are severely constrained in terms of ability to learn and accumulate human capital and by the type of skills and experience available to them. Our probit estimates suggest that illegal migrants returning home are $17,5 \%$ more likely to be unable to use the experiences and skills acquired during the migration spell.

Finally, it is interesting to note that return migrants who have accumulated savings abroad are less likely to put their skills to use upon return. This result might be explained by a higher reserve wage of those returnees who have accumulated sufficient savings which translates into a lower participation rate in the home country labour market. On the contrary, when technological knowhow is gained abroad there is a significant reduction of the probability of a skill waste when returning to the home country.

In the next step of our analysis, we analyse the probability of the returnees being currently economically inactive. From the point of view of the home country society this is probably the worst case scenario, as it severely limits the potential socio-economic benefits of return migration. Marginal effects obtained by estimating a probit model as in equation (1) above are reported in Table $3 .{ }^{6}$ As expected, older immigrants are more likely to be economically inactive. At mean value using the model in column (1), a 30 year old returnee has a probability of being currently inactive of $21,3 \%$ compared to $33,3 \%$ of that of a 50 year old. Female return migrants appear to be more likely to be economically inactive when returning home.

\footnotetext{
${ }^{6}$ Based on LR and Wald test on error terms correlation we reject the hypothesis of endogeneity of regressors - in particular on the dummy variable measuring skill waste during the migration spell - and hence we report only probit estimates in Table 3.
} 
TABLE 3 - HERE

We find evidence of a positive effect of household wealth before migration on the likelihood of being active in the job market. The probability of inactivity is approximately $22 \%$ higher for the returnees whose families were in debt and constantly borrowing for making a living before migration compared to those whose families were able to make substantial savings. This finding might be related to differences in the density and efficiency of social networks that are not cancelled out or mitigated by the migration experience. In line with the previous exercise, we find that holding a job before migration and migration for study purposes are associated with a lower probability of being inactive.

The probability of being economically inactive is higher for those individuals returning at the onset of the financial crisis (after 2009). The studies which investigate the reaction of workers to recession show that the immigrants are more responsive to labour shocks than the native workers (Boman, 2011). Therefore, during a strong recession foreign born individuals are more likely to spatially relocate (both internally and across borders), including the possibility of return to the home country. Our result suggests that individuals often do not return with 'a job in their hands ${ }^{77}$ and that it is likely that the crisis that affected many destination countries acted as a 'push' factor of return migration to Poland as documented in other studies (Zaiceva and Zimmermann, 2012).

We find evidence of that individuals experiencing a skill mismatch during migration are more likely to be economically inactive upon return (between 8,6 and $9,7 \%$ according to the model specification). Besides, when a returnee has been supported by the welfare state in the destination country (ex. unemployment benefits, child benefits) the likelihood of being unemployed is more than $17 \%$ higher.

Finally, it is interesting to note that migrants who have accumulated savings during the migration spell are significantly more likely to be economically inactive once they return. ${ }^{8}$

\section{TABLE 4 - HERE}

Return migrants might experience difficulties upon return which go beyond the inability to employ the newly acquired human capital or economic inactivity.

\footnotetext{
${ }^{7}$ See Herzog et al. (1993) for a survey of the empirical literature concerning the complex interrelationships between (un)employment status and migration. To our knowledge, the research on this issue is limited with respect to return migrants.

${ }^{8}$ Note that the effects of accumulated savings is positive and significant at all age levels although, as expected, stronger for older returnees (see figure in Appendix 2).
} 
As a final step of our analysis, we estimate equation (1), [and the joint estimates of the endogenous regressor version, eqs. (2) and (3)] using as dependent variable 'bitter return' a dummy equal to 1 when the returnee experiences significant hardship and/or difficulties upon return (and in particular those related to an entry into the job-market). In Table 4 we report the marginal effects of five alternative specifications. The first model (1 and 1a) is estimated using the full sample while model 2 is restricted to the returnees who were employed at the moment of the survey. Model 3 includes a set of dummies for the main countries of destination of the returnees. The last two specifications employ as dependent variable a dummy equal to 1 when job-related difficulties are experienced by the returnees. The main results highlighted above are partly confirmed when using a broad measure of unsuccessful return but new findings also emerge. A skill mismatch during migration is a strong predictor of further hardship and difficulties upon return, in particular in getting back into the home country labour market. Our preferred estimates, i.e. those correcting for the endogeneity of the skill mismatch during migration, imply an increase in the likelihood of difficulties upon return of more than $40 \%$ at mean values.

Individuals from poor households (as proxied by the importance of the migrants' remittances as a source of family income) and those using the welfare state in destination countries are more likely to experience a bitter return and more difficulties in getting a job upon return. This result might be related to a weaker social capital in the home country.

The social capital necessary for re-entering the home country labour market and society might be eroded as the migration spell increases. An additional year of migration increases the probability of a bitter return by approximately $3 \%$ at mean values.

Although younger individuals are less likely to be economically inactive or unemployed, they are more likely to face job related difficulties and more general hardships upon return. Job market search difficulties are approximately $10 \%$ less likely to happen for the returnees with tertiary education (model 5bis).

In support of the hypothesis of negative effects of savings accumulated abroad on the labour supply of the returnees, we find that this variable is positively related to a bitter return, but not to job market difficulties. This finding suggests that the higher probability of economic inactivity is likely to be (at least to a great extent) voluntary.

It is interesting to note that a bitter return is less likely for migrants returning from Germany and Scandinavian countries, but more likely for those returning from Italy (model 3). Note that immigrants in Italy are relatively more likely to have an illegal status and are often employed in low skilled and precarious occupations. More research in this respect is needed in order to disentangle the effects of an initial self-selection of immigrants into alternative destinations versus the effects of the characteristics of migration spells, which might as well be highly heterogeneous across countries.

Finally, we note that difficulties, in particular the job-related ones, are more likely for the immigrants who returned in 2009 and 2010, i.e. during the most negative phase of the current 
crisis. This evidence suggests that crisis might have substantial international spillovers which go beyond those related to the transmission of shocks through capital and financial markets.

\section{Conclusions}

International migration might represent an important channel through which countries and regions boost their economic potential in particular when migrants return to their home location with new financial and human resources. In this study we investigate the factors that might hamper the link between return migration and development using evidence from a representative sample of returnees in a large and relatively developed Polish region, Silesia. Although we focus on a specific region we believe that the analysis has important implications which might be arguably extended to several low and middle-income regions across the world with a rather intensive return of migrants.

Our analysis sheds light on the importance of the returnees' characteristics as well as on the context within which migration takes place in destination countries. We show that a skill mismatch during migration is often associated to a skill waste also when the migrants return home thus leading to a reduced economic potential embedded in return migration flows. Some groups of returnees are more vulnerable to a skill waste and more likely to experience economic inactivity compared to others. This is the case with older return migrants, females and individuals from less wealthy households. We also find that young return migrants, despite being quite effective in finding a job upon homecoming, were also more likely to face job-related difficulties and more general hardships (psychological, administrative) upon return.

Although a skill waste at the individual level does not necessarily translates into a negative effect at the aggregate level (see Ramos et al 2012 on over-education and regional growth), reducing hindrances to a better use of human resources by the returning diaspora might boost not only the individual returns from migration but also the social returns. Policies aimed at providing assistance to returnees - and in particular those who are likely to be more vulnerable - might be justified on these premises. Public institutions at regional level might play a role in facilitating burdensome administrative practices (for instance the certifications of diplomas and skills acquired abroad) and in matching skills of the returnees with those required by the local labour market.

We find evidence that the skill waste tends to be reduced over time as the returnees will readjust to the home country labour market but, admittedly, in this respect the cross-sectional nature of our data-set is a limitation of our analysis. A longitudinal and dynamic analysis of the performance of the returnees on the Silesian regional labour market would have been preferable in this respect. In particular, some soft skills acquired abroad might become a source of a competitive advantage of the returnee over non-migrating workers only after a certain period of time. Future studies on the labour market integration of return migrants should especially explore this direction of investigation. 


\section{References}

Anacka M., Fihel A. (2012), Return Migration to Poland in the Post-Accession Period, [in:] Galgóczi B., Leschke J., Watt A. (eds.), EU Labour Migration in Troubled Times. Skills Mismatch, Return and Policy Responses, Farnham: Ashgate Publishing Limited.

Baum, C., Dong, Y., Lewbel, A., and Yang, T. (2012), Binary choice models with endogenous regressors, Stata Users Group.

Bijwaard, G.E., and Wahba J., (2014), Do high-income or low-income immigrants leave faster?, Journal of Development Economics, 108 (2014): 54-68.

Bijwaard, G.E., Schluter, C., and Wahba J., (2014), The Impact of Labor Market Dynamics on the Return Migration of Immigrants, The Review of Economics and Statistics, July 2014, 96(3): 483-494.

Boman, A., (2011), The Mobility of Immigrants and Natives: Evidence from Internal Migration Following Job Displacement, Regional Studies, 45(3): 283-297.

Borjas, G. J., and Bratsberg, B., (1996), Who leaves? The outmigration of the foreign-born. Review of Economics and Statistics, 78(1): 165-176.

Brzozowski, J. (2011), Return migration of young Poles: implications for the regional labor markets, [in:] C. Larsen, R. Hasberg, A. Schmid, M. Bittner, F. Clement (eds.), Measuring Geographical Mobility in Regional Labour Market Monitoring. State of the Art and Perspectives, Rainer Hampp Verlag, Munchen 2011, p. 142-151.

Cerase, F. P. (1974), Expectations and reality: a case study of return migration from the United States to Southern Italy, International Migration Review, 8(2): 245-262.

Coniglio, N. D., De Arcangelis, G., and Serlenga, L. (2009), Intentions to return of clandestine migrants: The perverse effect of illegality on skills, Review of Development Economics, 13(4): 641-657.

CSO (2015), Local Data Bank, data-set provided by Central Statistical Office of Poland, available at: http://stat.gov.pl/bdlen/app/strona.html?p_name=indeks.

De Coulon, A., and Piracha, M. (2005), Self-selection and the performance of return migrants: the source country perspective, Journal of Population Economics, 18(4): 779-807.

De Haas, H., (2010), Migration and Development: A Theoretical Perspective, International Migration Review, 44(1): 227-264. 
De Haas, H., Fokkema, T., and Fihri, M. F. (2014), Return Migration as Failure or Success?. Journal of International Migration and Integration, 16(2): 415-429.

De Vreyer, P., Gubert, F., and Robilliard, A. S. (2010), Are there returns to migration experience? An empirical analysis using data on return migrants and non-migrants in West Africa, Annals of Economics and Statistics/Annales d'Économie et de Statistique, 307-328.

Diatta, M. A., and Mbow, N. (1999), Releasing the development potential of return migration: the case of Senegal, International Migration, 37(1): 243-266.

Dustmann, C. (1997), Return migration, uncertainty and precautionary savings, Journal of Development Economics, 52(2): 295-316.

Fokkema, T., and de Haas, H. (2015), Pre-and Post-Migration Determinants of Socio-Cultural Integration of African Immigrants in Italy and Spain, International Migration, 53(6): 3-26

Gmelch, G. (1980), Return migration, Annual Review of Anthropology, 9(1980): 135-159.

Herzog H.W., Schlottmann A.M., Boehm T.P. (1993), Migration as spatial job-search: A survey of empirical findings, Regional Studies, 27: 327-340

Iara, A., (2006), Skill diffusion by temporary migration? Returns to Western European working experience in the EU-accession countries, IEHAS Discussion Papers, No. MT-DP $2006 / 7$

Jensen, P., and Pedersen, P. J. (2007), To Stay or Not to Stay? Out-Migration of Immigrants from Denmark, International Migration, 45(5), 87-113.

Krings T, Bobek A, Moriarty E, Salamonska J and Wickham J (2009), Migration and recession: Polish migrants in post-Celtic Tiger Ireland, Sociological Research Online, 14(2).

Lianos, T. and Pseiridis, A., (2009), On-The-Job Skills and Earnings of Returned Migrants. International Migration - online first.

Martin, R., and Radu, D. (2012), Return Migration: The Experience of Eastern Europe, International Migration, 50(6): 109-128.

Mayer, S.D., Harima, A., and Freiling, J. (2015). Network Benefits for Ghanaian Diaspora and Returnee Entrepreneurs. Entrepreneurial Business and Economics Review, 3(3), 95-122.

McCormick, B., Wahba, J. (2001), Overseas work experience, savings and entrepreneurship amongst return migrants to LCDs, Scottish Journal of Political Economy, 48(2): 164-178.

Piracha, M., Vadean, F. (2010), Return Migration and Occupational Choice: Evidence from Albania, World Development, 38(8): 1141-1155.

Ramos, R., Surinach J., and M. Artis (2012), Regional Economic Growth and Human Capital: The Role of Over-Education, Regional Studies, 46(10): 1389-1400. 
Stark, O., Helmenstein, C., and Yegorov, Y. (1997), Migrants' savings, purchasing power parity, and the optimal duration of migration, International Tax and Public Finance, 4(3): 307-324.

Thistlethwaite F., (1960), Migration from Europe Overseas in the Nineteenth and Twentieth Centuries, XIe Congrès International des Sciences Historiques, Rapports (Uppsala 1960) [in:] A Century of European Migrations, 1830-1930, eds. R. Vecoli i S. Sinke, pp. 17-57, Urbana: University of Illinois Press, 1991.

Thomas-Hope, E. (1999), Return Migration to Jamaica and its Development Potential, International Migration, 37(1): 183-207.

Tilly, C. (2011), The impact of the economic crisis on international migration: a review, Work, Employment and Society, 25(4) 675-692

Williams, A.M., Balaz V., (2005), What Human Capital, Which Migrants? Returned Skill Migrants to Slovakia from the UK, International Migration Review, 39(2): 439-468.

Zaiceva, A. Zimmermann, K. F. (2012), Returning home at times of trouble? Return migration of EU enlargement migrants during the crisis, Discussion Paper Series No. 7111, Forschungsinstitut zur Zukunft der Arbeit, Bonn. 
Table 1. Return migrants in Silesia Region, Poland: some descriptive statistics

\begin{tabular}{|l|c|c|c|}
\hline Variable name & $\begin{array}{c}(1) \\
\text { All returnees }\end{array}$ & $\begin{array}{c}(3) \\
\text { Bitter return }\end{array}$ & Sweet return \\
Mean difference
\end{tabular}

Source: authors' calculations; note that $* * *$ and $* *$ represent statistical significances of mean differences at respectively $5 \%$ and $10 \%$.

Table 2 - The probability of skill waste upon return migration (marginal effects)

\begin{tabular}{|c|c|c|c|c|c|c|}
\hline $\begin{array}{l}\text { Dependent variable: skill waste } \\
\text { upon return }\end{array}$ & (1) Probit & $\begin{array}{l}\text { (1a) Bivariate } \\
\text { Probit }(*)\end{array}$ & (2) Probit & $\begin{array}{l}\text { (2a) Bivariate } \\
\text { Probit }(*)\end{array}$ & (3) Probit & $\begin{array}{l}\text { (3a) Bivariate } \\
\text { Probit }(*)\end{array}$ \\
\hline Age & $.007 * * *(.002)$ & $.005 * * *(.002)$ & $.0060 * *(.002)$ & $.005 * * *(.002)$ & $.0054 * *(.002)$ & $.004 * *(.002)$ \\
\hline Female & $.107 *(.055)$ & $.077 *(.044)$ & $.0957 *(.056)$ & $.078 *(.047)$ & $.0904(.059)$ & $.068(.044)$ \\
\hline Vocational education & $-.00534(.075)$ & $.028(.061)$ & $-.0102(.076)$ & $.017(.066)$ & $-.0386(.078)$ & $.0040(.063)$ \\
\hline Tertiary education & $-.136 *(.078)$ & $-.129 * *(.061)$ & $-.133 *(.078)$ & $-.129 * *(.064)$ & $-.152 *(.081)$ & $-.136 * *(.063)$ \\
\hline $\begin{array}{l}\mathrm{HH} \text { economic situation before } \\
\text { migration }\end{array}$ & $-.0486 *(.026)$ & $-.032(.022)$ & $-.0414(.027)$ & $-.032(.023)$ & $-.0454 *(.028)$ & $-.030(.022)$ \\
\hline Employed before migration & $-.119 * *(.053)$ & $-.078 *(.046)$ & $-.113 * *(.053)$ & $-.085 *(.048)$ & $-.105^{*}(.054)$ & $-.067(.045)$ \\
\hline Main reason to migrate: study & $-.224 * *(.114)$ & $-.115(.101)$ & $-.215^{*}(.115)$ & $-.135(.108)$ & $-.166(.121)$ & $-.0685(.099)$ \\
\hline Year of return & $-.0099(.015)$ & $-.0057(.011)$ & $-.0074(.015)$ & $-.0052(.012)$ & $.00035(.016)$ & $-.001(.011)$ \\
\hline $\begin{array}{l}\text { Social assistance in the host } \\
\text { country }\end{array}$ & $.0952(.067)$ & $.098 *(.056)$ & $.106(.066)$ & $.105 *(.059)$ & $.127 *(.066)$ & $.116^{* *}(.057)$ \\
\hline Migration spell (in months) & $-.002 * * *(.001)$ & $-.001 * *(.001)$ & $-.002 * * *(.001)$ & $-.002 * *(.001)$ & $-.002 * * *(.001)$ & $-.001 * *(.001)$ \\
\hline Skill mismatch during migration & $.126^{* *}(.050)$ & $.381 * * *(.099)$ & $.120 * *(.051)$ & $.317 * *(.149)$ & $.107 * *(.053)$ & $.357 * * *(.115)$ \\
\hline Irregular migration & & & $.175^{*}(.094)$ & $.113(.113)$ & $.155(.098)$ & $.069(.101)$ \\
\hline Accumulated savings & & & & & $.114 * *(.052)$ & $.089 * *(.039)$ \\
\hline Learned a language & & & & & $-.089(.059)$ & $-.071(.045)$ \\
\hline Acquired soft-skills & & & & & $-.082(.053)$ & $-.0631 *(.039)$ \\
\hline $\begin{array}{l}\text { Acquired technological } \\
\text { knowhow }\end{array}$ & & & & & $\begin{array}{l}-.159 * * * \\
(.055)\end{array}$ & $-.110 * *(.046)$ \\
\hline Rho & & $-.592 *(.28)$ & & $-.434(.356)$ & & $-.592(.310)$ \\
\hline LR test Rho $=0(\operatorname{chi} 2(1))$ & & $2.839^{*}$ & & 1.627 & & 2.139 \\
\hline $\begin{array}{l}\text { Pseudo R2 } \\
\text { Observations }\end{array}$ & $\begin{array}{l}.089 \\
431\end{array}$ & & $\begin{array}{l}.094 \\
431\end{array}$ & & $\begin{array}{l}.129 \\
431\end{array}$ & \\
\hline
\end{tabular}

Note: Marginal effects from probit estimates are reported / for dummy variables marginal effects are calculated as discrete change from 0 to 1. Standard errors in parentheses $* * * \mathrm{p}<0.01, * * \mathrm{p}<0.05,{ }^{*} \mathrm{p}<0.1$

The second equation in the bivariate model is the following: Skill mismatch during migration (dependent variable) = Germany, UK, Ireland,

Scandinavian country, Italy, vocational education, tertiary education, economic situation before migration, employed before migration, main reason to migrate is study, social assistance in the host country, migration spell, irregular migration 


\begin{tabular}{|c|c|c|c|c|}
\hline $\begin{array}{l}\text { Dependent variable: currently economically } \\
\text { inactive }\end{array}$ & (1) & (2) & (3) & (4) \\
\hline Age & $\begin{array}{c}0.00594 * * * \\
(0.00207)\end{array}$ & $\begin{array}{c}0.00583 * * * \\
(0.00204)\end{array}$ & $\begin{array}{c}0.00650 * * * \\
(0.00204)\end{array}$ & $\begin{array}{c}0.00615 * * * \\
(0.00206)\end{array}$ \\
\hline Female & $\begin{array}{l}0.113 * * \\
(0.0479)\end{array}$ & $\begin{array}{l}0.112 * * \\
(0.0487)\end{array}$ & $\begin{array}{c}0.0758 \\
(0.0486)\end{array}$ & $\begin{array}{l}0.0903 * \\
(0.0501)\end{array}$ \\
\hline Vocational education & $\begin{array}{l}-0.0465 \\
(0.0564)\end{array}$ & $\begin{array}{l}-0.0597 \\
(0.0571)\end{array}$ & $\begin{array}{l}-0.0655 \\
(0.0564)\end{array}$ & $\begin{array}{l}-0.0735 \\
(0.0565)\end{array}$ \\
\hline Tertiary education & $\begin{array}{l}-0.0625 \\
(0.0574)\end{array}$ & $\begin{array}{l}-0.0876 \\
(0.0575)\end{array}$ & $\begin{array}{l}-0.106^{*} \\
(0.0557)\end{array}$ & $\begin{array}{l}-0.104^{*} \\
(0.0568)\end{array}$ \\
\hline HH economic situation before migration & $\begin{array}{c}-0.0557^{* *} \\
(0.0221)\end{array}$ & $\begin{array}{c}-0.0549^{* *} \\
(0.0228)\end{array}$ & $\begin{array}{c}-0.0485^{* *} \\
(0.0225)\end{array}$ & $\begin{array}{c}-0.0491 * * \\
(0.0225)\end{array}$ \\
\hline Employed before migration & $\begin{array}{c}-0.0862^{* *} \\
(0.0429)\end{array}$ & $\begin{array}{c}-0.0872 * * \\
(0.0435)\end{array}$ & $\begin{array}{l}-0.105^{* *} \\
(0.0433)\end{array}$ & $\begin{array}{c}-0.0963 * * \\
(0.0435)\end{array}$ \\
\hline Man reason to migrate: study & $\begin{array}{l}-0.145^{* *} \\
(0.0590)\end{array}$ & $\begin{array}{c}-0.159 * * * \\
(0.0552)\end{array}$ & $\begin{array}{r}-0.144 * * \\
(0.0591)\end{array}$ & $\begin{array}{l}-0.123^{*} \\
(0.0700)\end{array}$ \\
\hline Year of return & $\begin{array}{c}0.0699 * * * \\
(0.0138)\end{array}$ & & & \\
\hline Year of return: 2008 & & $\begin{array}{l}-0.0199 \\
(0.0663)\end{array}$ & $\begin{array}{l}-0.0310 \\
(0.0646)\end{array}$ & $\begin{array}{l}-0.0272 \\
(0.0648)\end{array}$ \\
\hline Year of return: 2009 & & $\begin{array}{c}0.0749 \\
(0.0693)\end{array}$ & $\begin{array}{c}0.0706 \\
(0.0690)\end{array}$ & $\begin{array}{c}0.0872 \\
(0.0704)\end{array}$ \\
\hline Year of return: 2010 & & $\begin{array}{l}0.190 * * \\
(0.0743)\end{array}$ & $\begin{array}{l}0.189 * * \\
(0.0754)\end{array}$ & $\begin{array}{l}0.193 * * \\
(0.0760)\end{array}$ \\
\hline Year of return: 2011 & & $\begin{array}{c}0.483 * * * \\
(0.103)\end{array}$ & $\begin{array}{c}0.469 * * * \\
(0.108)\end{array}$ & $\begin{array}{c}0.506^{* * *} \\
(0.107)\end{array}$ \\
\hline Skill mismatch during migration & & & $\begin{array}{l}0.0862 * \\
(0.0459)\end{array}$ & $\begin{array}{l}0.0970 * * \\
(0.0466)\end{array}$ \\
\hline Social assistance in the host country & & & $\begin{array}{l}0.174^{* *} \\
(0.0706)\end{array}$ & $\begin{array}{l}0.180^{* *} \\
(0.0714)\end{array}$ \\
\hline Accumulated savings & & & & $\begin{array}{l}0.0881 * * \\
(0.0417)\end{array}$ \\
\hline Learned a language & & & & $\begin{array}{l}-0.0497 \\
(0.0527)\end{array}$ \\
\hline Acquired soft-skills & & & & $\begin{array}{l}-0.0558 \\
(0.0448)\end{array}$ \\
\hline $\begin{array}{l}\text { Pseudo R2 } \\
\text { Observations }\end{array}$ & $\begin{array}{c}0.14 \\
415\end{array}$ & $\begin{array}{l}0.16 \\
421\end{array}$ & $\begin{array}{l}0.19 \\
418\end{array}$ & $\begin{array}{l}0.20 \\
418\end{array}$ \\
\hline $\begin{array}{l}\text { Observations } \\
\text { Note: for dummy variables marginal effects are c } \\
\text { Standard errors in parentheses } * * * \mathrm{p}<0.01, * * \mathrm{p}<0\end{array}$ & $\begin{array}{l}\quad 415 \\
\text { ed as discrete } \\
p<0.1\end{array}$ & $\begin{array}{l}421 \\
\text { e from } 0 \text { to } 1 .\end{array}$ & 418 & 418 \\
\hline
\end{tabular}




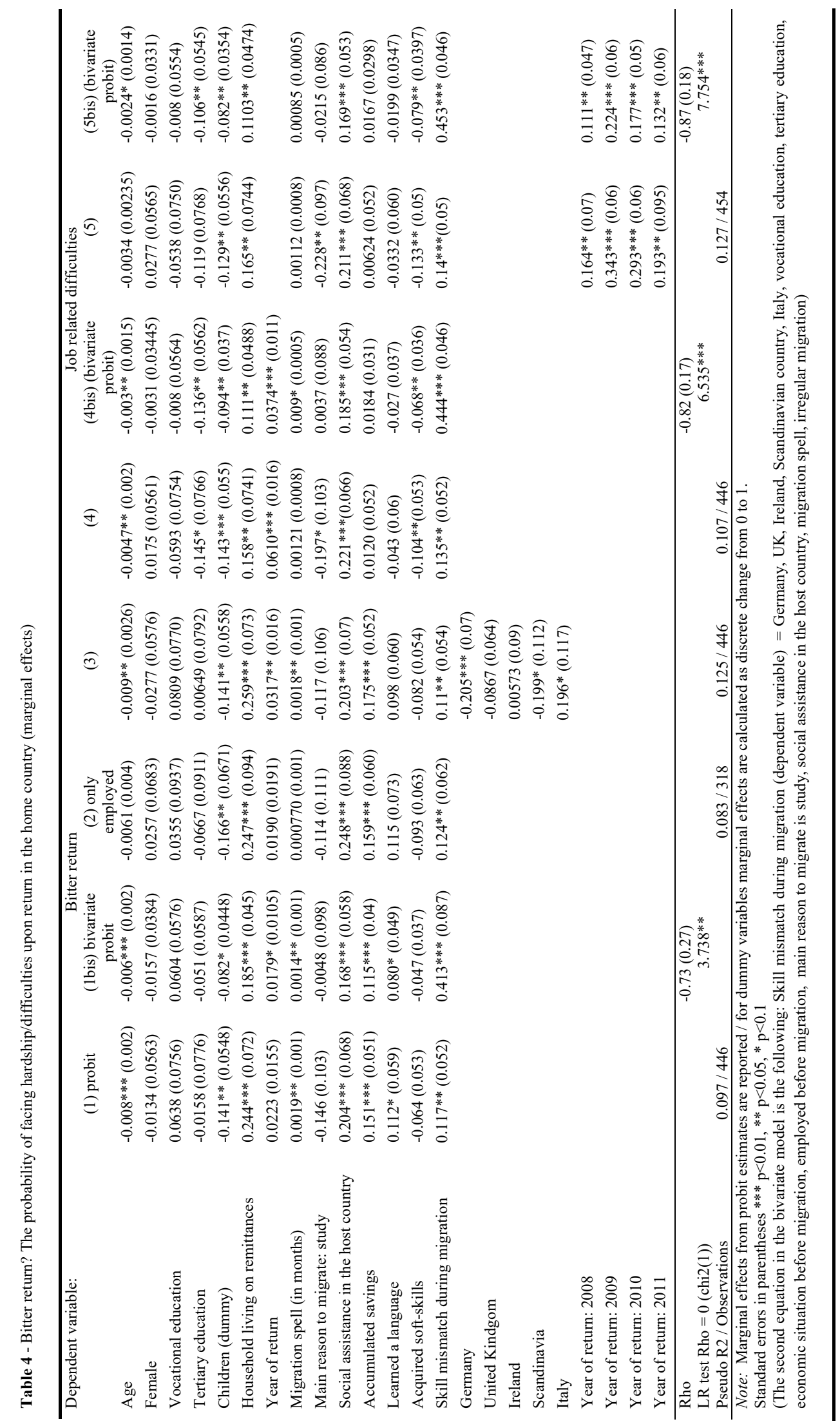




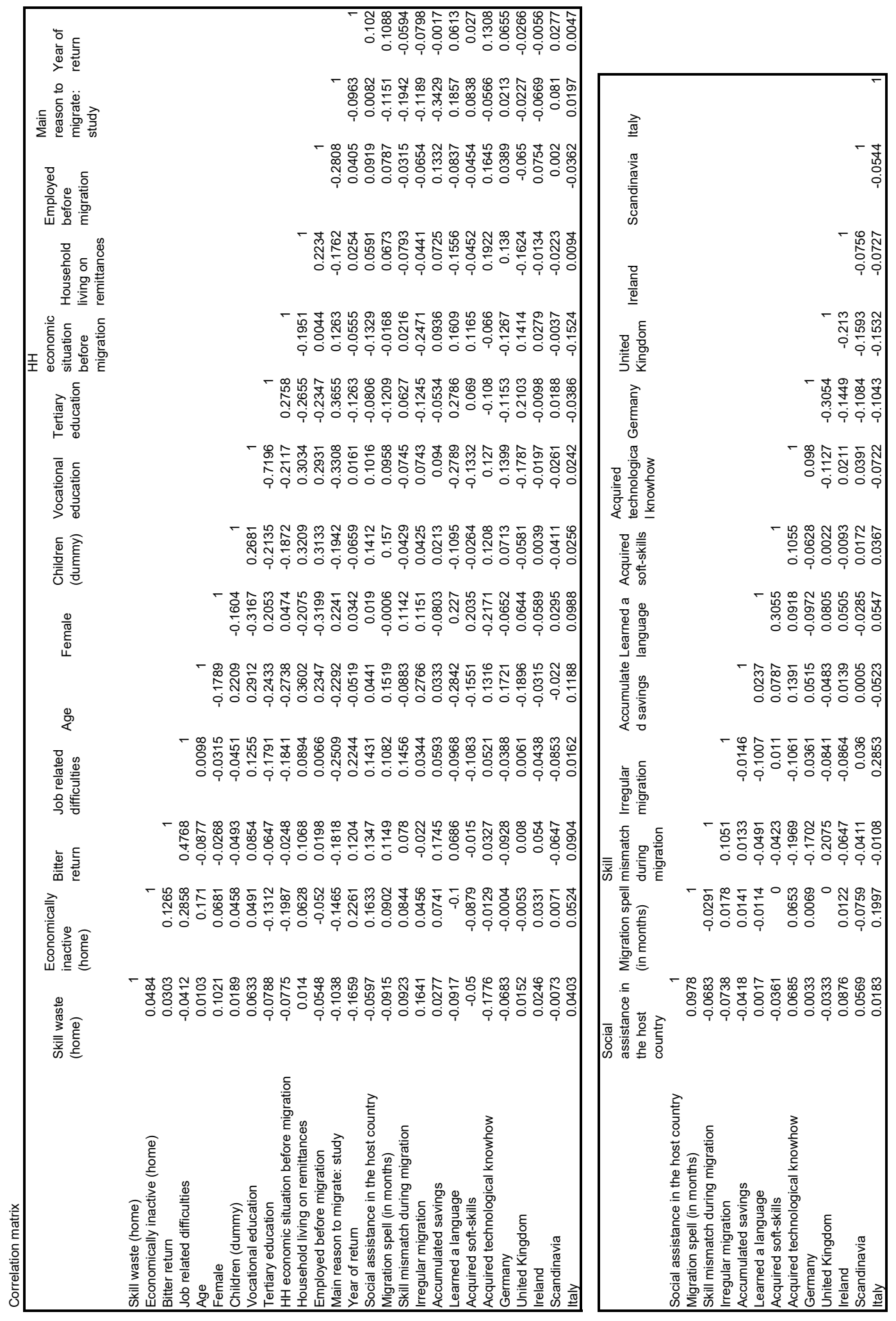

